коммерческих рисков, их минимизация, способы страхования; определение эффективной маркетинговой стратегии, выбор организационной формы создания, освоения и размещения на рынке новшеств; оценка идей по созданию новшеств, управление персоналом, занятым в разработке и производстве новшества, обеспечение благоприятного климата и корпоративной культуры.

Такое состояние инновационной системы, при котором обеспечивается эффективное и согласованное функционирование всех внутренних и внешних ее элементов, можно назвать гармонией. Поэтому функциональная определенность управления инновационным процессом заключается в достижении гармонии в развитии инновационного предприятия.

Отличительной чертой института инновационного менеджмента является относительно большая независимость выбора альтернативного решения, хотя при этом выбор способов поведения тесно связан с присутствием в мотивационной структуре личности профессиональной компетентности и личной ответственности . Становление инновационного менеджмента тесно связано с «освобождением» личности и повышением уровня межличностных коммуникаций, переходом от безличного подхода к управлению персоналом к персонализированному. При этом творческий процесс создания новшества становится предметом свободного нравственного и эмоционального выбора индивида.

Функциональная определенность инновационного менеджмента заключается в эффективном управлении процессами разработки, внедрения, производства и коммерциализации новшеств. Задачами инновационною менеджера являются обеспечение оптимального функционирования операционной системы производства, синхронизации функциональных подсистем, совершенствование системы управления персоналом и осуществление контроля.

Отрах В.В., Самойлов М. А.

Функции процесса управления инновационного менеджмента

Московский технологический институт (Россия, Москва) doi:10.18411/1j2016-4-17

Различают две группы функций процесса управления инновационной деятельностью. Это основные и обеспечивающие функции. Основные функции - это стратегическое планирование, организация, мотивация и контроль. Основные функции инновационного менеджмента являются общими для всех видов и любых условий осуществления инновационных проектов, они отражают содержание основных стадий управления инновационной деятельностью. К обеспечивающим функциям инновационного менеджмента относят функции, способствующие эффективному осуществлению основных функций: социально-психологические, технологические, процессуальные. Социально-психологические функции менеджмента связаны с состоянием производственных отношений в коллективе.

Следует различать такие разновидности функции менеджмента, как делегирование и мотивацию. К функции делегирования относится 
комплекс управленческих решений, способствующих рациональному распределению работ по управлению инновационными процессами и ответственности за их осуществление между сотрудниками аппарата управления. Делегированием можно считать ситуацию, когда заказчик делегирует полномочия по руководству работами по инновационному проекту руководителю проекта.

Функция мотивации направлена на создание системы моральных и материальных стимулов для сотрудников организации, обеспечение их профессионального уровня и возможности карьерного роста, то есть на создание условий, оказывающих воздействие на поведение человека. Рациональное соотношение делегирования полномочий и мотивации труда исполнителей - главное условие успешного менеджмента в инновациях.

К числу обеспечивающих относятся также технологические функции, которые позволяют реализовать основные и социальнопсихологические функции и включают подготовку, получение, переработку и передачу информации для успешного продвижения инноваций.

Bce перечисленные функции инновационного менеджмента взаимосвязаны между собой, дополняют друг друга, создают целостную функциональную систему инновационного менеджмента, его функциональную определенность. В основе инновационной деятельности лежит научно-техническая деятельность, тесно связанная с созданием, развитием, распространением и применением научно-технических знаний во всех областях науки и техники.

К инновационной деятельности относится вся деятельность в рамках инновационного процесса, в том числе маркетинговые исследования в отношении освоения новых рынков и поиск новых потребителей, информационное обеспечение возможной конкурентной среды и потребительских свойств товаров конкурирующих фирм, поиски новаторских идей и решений, партнеров по внедрению и финансированию инновационного проекта, а также разработка, внедрение новых прогрессивных методов управления с использованием новейших информационных технологий.

Объект инновационной деятельности представляет собой процесс разработки новых продуктов, техники, технологии, создание новой отрасли, придание новых свойств товару, нахождение новых сегментов потребителей предприятиями, находящимися на территории Российской Федерации, независимо от формы собственности. Субъектами инновационной деятельности выступают юридические лица вне зависимости от форм собственности, физические лица, иностранные хозяйствующие субъекты и граждане, а также лица без гражданства, вовлеченные в процесс создания инноваций. Инновационная деятельность должна базироваться на следующих принципах: достижение высокой экономической результативности инновационного производства посредством превосходства новых методов производства над традиционными по количественным и качественным показателям; гибкость производства, возможность преобразования производства создания самостоятельной инновационной структуры в соответствии с потребностями, возникающими в процессе реализации новой идеи; 
комплексный характер инновационного процесса в следствии появления целой совокупности сопутствующих основной инновации более мелких научных, технологических и организационно-управленческих новшеств.

В целях создания системы управления инновационной деятельностью, формирования целевой функции управления, постановки задач, прогнозирования экономических результатов, формирования организационных и производственных структур, на наш взгляд, необходимо освоение особого вида профессиональной деятельности инновационный менеджмент.

В общеэкономической трактовке инновационный менеджмент выступает как совокупность научно обоснованных принципов, форм, методов, приемов и средств управления инновациями в сфере их создания, освоения, производства и продвижения на рынок с целью максимизации прибыли. Инновационный менеджмент рассматривает специфические формы управления в сфере инноваций, инновационных процессов, осуществляемых всеми хозяйствующими субъектами, во всех сферах национальной экономики. Инновационный менеджмент как наука управления представляет собой систему знаний о способах наиболее рациональной организации управления инновационными процессами и инновационной деятельностью для достижения стратегических целей и решения тактических задач.

Фундаментальным критерием экономического развития на современном этапе становится понимание человеческих и интеллектуальных ресурсов с позиций их непреходящей ценности. С точки зрения важности ресурсов экономического роста первостепенной является тесная связь интеллектуального потенциала с требованиями передового научно-технического развития и трудовой мотивацией, выступающей как поведенческая установка.

Инновационная направленность экономических процессов, присущих современной мировой экономике, доказала неэффективность организационных структур и методов классического менеджмента, не учитывающих возрастающего значения нематериальных форм и нетрадиционных качественных факторов экономического роста. Концептуальные положения и принципы традиционного классического менеджмента уступают место новым моделям инновационного управления.

Уделяя значительное внимание инновационному менеджменту как функциональной системе управления, многие авторы в экономической литературе характеризуют его как самостоятельную область экономической науки и профессиональной деятельности, направленную на формирование и обеспечение достижения организационной структурой инновационных целей путем рационального использования материальных, трудовых и финансовых ресурсов.

С таких позиций инновационный менеджмент представляет собой одну из многочисленных разновидностей функционального менеджмента, непосредственным объектом которого выступают инновационные процессы во всех сферах и областях народного хозяйства.

Содержание понятия «инновационный менеджмент» может рассматриваться, по крайней мере, в трех аспектах: как науку и искусство 
управления инновациями, как вид деятельности и процесс принятия управленческих решений в инновациях и как аппарат управления инновациями. Такое широкое понимание сущности и принципов инновационного менеджмента противоречит узким рамкам функциональной концепции.

Новая методологическая и научная ориентация инновационного менеджмента основана на качественной уникальности теоретического уровня знания и его главенствующей роли в национальном богатстве. При инновационной направленности экономического роста модели исследовательского процесса создания нового научного знания и процедуры возникновения новых интеллектуальных продуктов прочно занимают определяющее место.

С этой точки зрения инновационный менеджмент приобретает институциональное значение, предполагающее включение в его понятие и структурного оформления инновационной сферы, и системы управления инновациями, состоящей из специализированных органов управления, и наличие специального института менеджеров, наделенных полномочиями принимать решения и нести ответственность за результаты инновационной деятельности.

Инновационный менеджмент как система является набором взаимодействующих формальных и неформальных правил, принципов, норм, установок и ценностных ориентаций, регулирующих различные сферы инновационной деятельности. В концепции формирования постиндустриального общества инновационный менеджмент представляет собой экономическую систему.

В инновационном менеджменте, как нам представляется, следует выделять два уровня. Первый представлен теориями социального управления инновационными системами и концентрирует усилия на разработке стратегий инновационного развития, социальноорганизационных изменений, а также других экономических и социальнофилософских концепций, объясняющих механизм функционирования экономической системы.

Второй уровень инновационного менеджмента являет собой прикладные теории организации и управления инновационной деятельностью, а потому носит функциональный прикладной характер и обеспечивает научно-методическую базу для разработки практических решений по совершенствованию управления, анализа инновационной деятельности, применению новейших приемов и методов воздействия на персонал, технико-технологические системы, продуктовые и финансовые потоки.

\section{Распопин Е.B.}

Совесть как морально-психологическая и экзистенциальная характеристика личности

Уральский юридический институт МВД России (Россия, Екатеринбург) doi:10.18411/1j2016-4-18 